\title{
ECONOMIA, ESPAÇO E GLOBALIZAÇÃO NA AURORA DO SÉCULO XXI
}

\author{
MARIA LUCINDA FONSECA ${ }^{1}$
}

As transformações económicas, sociais e políticas que têm vindo a verificar-se neste fim de milénio, num quadro de crescente globalização, têm sido acompanhadas e em parte induzidas, por profundas alterações de natureza geográfica.

Identificar e compreender os mecanismos que estão na origem deste mundo novo e dos processos de mudança das configurações territoriais, é o objectivo principal deste livro de Georges Benko².

A obra está estruturada em três partes fundamentais. Na primeira, o autor faz uma síntese do contexto socioeconómico que conduziu à crise que se seguiu ao período de expansão económica do segundo pós-guerra e das condições de passagem de um regime de acumulação fordista para outro pós-fordista e flexível.

A segunda parte é dedicada ao estudo do sistema produtivo actual, com especial ênfase no processo de reestruturação industrial e na expansão das actividades de alta tecnologia que estão na base do desenvolvimento das sociedades cognitivas actuais. Na tentativa de encontrar explicações para a persistência da crise económica iniciada nos anos setenta, revisita as concepções teóricas shumpeterianas e neo-shumpeterianas e detém-se nas abordagens regulacionistas. Analisa, em seguida, a lógica de localização da indústria de alta tecnologia e suas relações com o desenvolvimento regional, tratando, em particular, das condições de emergência dos tecnopolos e dos novos espaços industriais nas economias mais desenvolvidas.

Na última parte do livro, Georges Benko procura demonstrar a validade dos princípios que apresenta nos capítulos anteriores e aplicar à análise do caso francês os conceitos utilizados pela geografia económica contemporânea para se ajustar à evolução da economia e às mudanças na organização territorial da produção na transição para o século XXI. Trata em primeiro lugar, da dinâmica recente da organização do território da França e, no capítulo seguinte, concentra-se na análise do mais importante espaço industrial de alta tecnologia do país: a Cité Scientifique de Ile de France.

O trabalho termina com um glossário utilíssimo para quem pretenda conhecer o léxico fundamental da economia e da geografia económica na actualidade.

Ao longo de todo o livro, o autor conjuga a análise histórica com uma perspectiva de abordagem sistémica. A organização da produção mundial é vista como um sistema global, constituído por um mosaico de regiões produtivas especializadas, com processos complexos de crescimento localizados, e cada vez mais dependentes de outras regiões.

A problemática do global e do local é encarada sob uma mesma lógica e, por conseguinte, a questão do desenvolvimento regional é interpretada à luz da teoria da

\footnotetext{
1 Professora Associada da FLUL e investigadora do Centro de Estudos Geográficos da Universidade de Lisboa. Alameda da Universidade 1699 LISBOA CODEX. Tel.: (351-1) 7940218; Fax: (351-1) 7938690; e-mail: ceg@mail.telepac.pt

2 BENKO, Georges (1996) - Economia, Espaço e Globalização na Aurora do Século XXI. S. Paulo, Hucitec, 266 pp.
} 
regulação, da noção de governância e do duplo processo de aglomeração e segmentação inerente à lógica da divisão do trabalho.

Este livro de Georges Benko representa um valioso contributo para compreender os mecanismos de transformação da economia e da organização territorial da produção, especialmente do sector industrial, nas duas últimas décadas.

A importância e actualidade dos temas que trata e a clareza com que os analisa, fazem desta obra um instrumento de apoio fundamental para a aprendizagem e o ensino das matérias da geografia económica contemporânea. 